\title{
REVIEW
}

\section{Puerto Rican Drag}

\author{
H. Manuel Acevedo-Reyes \\ University of Virginia, US \\ hma7x@virginia.edu
}

Review of Lawrence La Fountain-Stokes. Translocas: The Politics of Puerto Rican Drag and Trans Performance. University of Michigan Press, 2021. 356 pages.

Keywords: Puerto Rico; Drag; Trans Studies; Queer; Gender and Sexuality; Latinx

On February 24th 2020, the lifeless body of Alexa Negrón Luciano, a homeless transgender woman, was found in Toa Baja, Puerto Rico. Her body was found hours after a female McDonald's costume accused her of using the women's bathroom in order to spy on other women with a mirror. In the hours between the accusation and the finding of her body, Alexa suffered from harassment, and violence, both verbal and physical (Roure). The story of Alexa shows the precarity and vulnerability of individuals who dare to challenge dominant views of gender and sexuality in the colonial space of Puerto Rico. In Translocas: The Politics of Puerto Rican Drag and Trans Performance Lawrence La Fountain-Stokes aims to provide a new analytic lens with which to investigate the ways in which trans and drag performers reject and/or assimilate into hegemonic ideologies of gender, sexuality and race and its intersection with national identity, class and justice. This work can be seen as a "crónica, testimonio, or auto-ethnographic reflection of a self-identified Puerto Rican transloca" (6). Indeed, there is a constant presence of the self, often represented as part of a collective identity expressed through the collective pronoun, we. The transloca lens that La Fountain-Stokes proposes provides the opportunity to analyze the often-contradictory spaces and contexts in which these performances take place.

What is a transloca? What are the potential dangers that translocas pose for society? What are the dangers that society represents for them? These are the questions that the author raises in the pages of this book. While these are the questions for which there is no easy answer, in the introduction, La Fountain-Stokes proposes that they are "performers, innovators, marginals, exiles, eccentrics, troublemakers, lovers, loners, and friends who live in a transnational/translocal context marked by cultural, racial, and linguistics, mixtures and juxtapositions" (18). This general description is merely a starting point for describing and recognizing translocas for they are contradictory and unique. Originating as the union of "trans" as meaning both gender nonconformity and in relation to spatial movement, with "loca" as the once pejorative Spanish denoting an effeminate homosexual, similar to English's "sissy," the neologism proves to be elastic. Indeed, although La Fountain-Stokes uses it mostly to describe trans and drag performers who belong to el ambiente (individuals part of, or in the know of, queer life), it can also be employed to describe women who embody an excess of femininity, as is the case of performance artist Erika Lopez. In the case of Puerto Rico, Translocas need to be understood as colonial formations, as individuals who are very much informed by the exchanges between Puerto Rico and the United States. Translocas are formed in the intersection between a global context and local knowledge.

Divided into seven chapters, an introduction and an epilogue, Translocas employs an extensive corpus of scholarship on Latin American, Caribbean and Latinx literary and cultural production, historical (often tragic) events and the lives of various individuals. In Chapter 1, La Fountain-Stokes engages current Latin American, Caribbean and Latinx feminist and gender and sexuality scholarship to explain the ambiguous place that the term loca, and the neologism transloca, has within this academic production where it is sometimes embraced due to its disruptive and radical potential, but often rejected due to the pathologizing 
and stigma that follows it. Chapter 2 explores "the continuing precarious position of transloca subjects" (62) through a discussion of Nina Flowers, a drag queen and television personality, and her absorption into the U.S. neoliberal capitalist system through her participation in for-profit transloca performances. It also highlights the murders of activist Jorge Steven López Mercado and trap artist Kevin Fret, two murdered cuir (queer) men, paying close attention to the mass media reaction and portrayal of the events. Chapter 3 explores the relationship between transloca performance and poverty, particularly how transloca performance allows us to engage with and challenge the state of decadence in which translocas find themselves due to the neoliberal state.

In the last four chapters of the book, La Fountain-Stokes engages deeply with themes of race, migration and social relations. Chapter 4 is interested in Freddie Mercado's performances using the framework of rasanblaj (compilation of ideas) and ultrabaroque (New World baroque) to explore the ways in which Mercado's performance challenges race, gender, sexuality and human relations to nonhumans. Chapter 5 centers around Javier Cardona's transloca drag of race in order to show how transloca performers engage and challenge racial expectations and imposition. While race is part of Mercado's critique, in Cardona's performance, it takes center stage. In Chapter 6's exploration of the connection between music, gender identity, and migration, La Fountain-Stokes centers his discussion around El Bolero, which he claims "creates, destroys, and confuses, as it mediates between generation, states of sanity, gender perceptions, and body relations" (171) as evidenced in Ramos Otero's short story and Merced's adaptation, in relation to Merced, he is particularly interested in the transloca embodiment as one that can lead to community building. In Chapter 7, La Fountain-Stokes explores two potentials of transloca performance: community building and social transformation.

La Fountain-Stokes employs a wealth of sources throughout his analysis in this book. Some sources come from canonical Caribbean literature (Antes de que anochezca, "Loca la de la locura"), television shows and personalities (RuPaul's Drag Race, Walter Mercado), music (Kevin Fret), the lives and activism of translocas (Jorge Steven López Mercado, Holly Woodlawn, Sylvia Rivera) and transloca stage performers (Nina Flowers, Erika Lopez, Monica Beverly Hillz, Freddie Mercado, Javier Cardona, Jorge Merced, Lady Catiria, Barbra Herr). These sources, amongst many others, provide La Fountain-Stokes with a wide range of mediums to which apply the transloca lens that he is proposing in this book.

This book is in itself a contradiction at times about the forms of kinship and the networks of cares that these performers establish for themselves and each other, and at other times about the ever-present violence that these individuals are often subjected to. For instance, the second chapter centers around the deadly physical violence that claimed the lives of translocas Jorge Steven López Mercado and Kevin Fret. In the case of the gender nonconforming López Mercado, La Fountain-Stokes centers on their violent death and the media's reactions to their murder. He shows that there was an attempt to sanitize their image, particularly through hiding his association with sex workers. This was made in an attempt to make them seem more innocent, which in turn hid their activism and overall commitment to social justice, thus erasing López Mercado's informed transloca performativity. In the case of Fret, La Fountain-Stokes opted to focus on Fret's assertive articulation of transloca performativity through his refusal to adhere to gender expectations. In comparison to another gender nonconforming trapero, Bad Bunny, Fret "extensively used facial makeup, referred to himself as a loca and pato, sexualized his body for men, flirted with violence, and suffered the deadly consequences" (69). La Fountain-Stokes benefits from a dialogue with Southern Cone's transvestite and cuir studies due to the violence of both cases. For these two gender and sexual dissidents, same as those in the Southern Cone, there is an overall lack of familial and state protection that often, leads to their death (Perlongher; Wayar).

This book is essential for scholars interested in gender and sexuality in the Caribbean and Latinx literary and cultural production, particularly to those interested in Puerto Rico. La Fountain-Stokes's engagement with current scholarship and his contributions to this scholarship will greatly benefit specialists and scholars new to the field. The author's own experiences as a transloca performer himself adds a welcome and timely ethnographic value to the book. Indeed, the author's drag persona's, Lola Von Miramar, importance in this book is made explicit as La Fountain-Stokes points out that at times, the transloca theory that he is proposing here could be "Lola Von Miramar's delusions" (19). Delusion or not, a transloca lens offers a unique opportunity to consider not only the lives of the subjects that populate the pages of this book, but also their representation.

\section{Competing Interests}

The author has no competing interests to declare. 


\section{References}

Perlongher, Néstor. Prosa Plebeya: Ensayos 1980-1992. Ediciones Colihue, 1996.

Roure, Jodie G. "The Reemergence of Barriers during Crises \& Natural Disasters: Gender-Based Violence Spikes among Women \& LGBTQ+ Persons during Confinement." Seton Hall Journal of Diplomacy and International Relations, vol. 21, no. 2, 2020, pp. 23-50.

Wayar, Marlene. Travesti: Una teoría lo suficientemente buena. Editorial Muchas Nueces, 2018.

How to cite this article: Acevedo-Reyes, HM 2021 Puerto Rican Drag. Anthurium, 17(1): 4, 1-3. DOI: https://doi. org/10.33596/anth.451

Published: 01 September 2021

Copyright: (c) 2021 The Author(s). This is an open-access article distributed under the terms of the Creative Commons Attribution 4.0 International License (CC-BY 4.0), which permits unrestricted use, distribution, and reproduction in any medium, provided the original author and source are credited. See http://creativecommons.org/licenses/by/4.0/. 